\author{
ANDRZEJ FRISZKE \\ Instytut Studiów Politycznych PAN, Warszawa
}

\title{
INTERNOWANI, ARESZTOWANI, SKAZANI. POZBAWIENI WOLNOŚCI W OKRESIE STANU WOJENNEGO 1981-1983/1984
}

\begin{abstract}
Abstrakt: Do najbardziej charakterystycznych cech stanu wojennego należało internowanie obywateli na zasadzie swobodnej decyzji władz, a także aresztowanie i skazywanie osób, które naruszyły wprowadzone 13 grudnia 1981 r. drakońskie prawa. Liczba internowanych ulegała zmianie od chwili wprowadzenia stanu wojennego do jego zawieszenia, które nastąpiło w grudniu 1982 r., kiedy możliwość internowania przestała istnieć. Nadal jednak obowiązywały surowe paragrafy wymierzone przeciw wolnościom obywatelskim, które - po zniesieniu stanu wojennego - przeniesiono do kodeksu karnego.
\end{abstract}

Słowa kluczowe: stan wojenny, internowani, uwięzieni, skazani, amnestie, Solidarność, opozycja polityczna
Abstract: One of the most characteristic features of the martial law in Poland was the internment of citizens by the arbitrary decision of the authorities, and also detention and conviction of people who infringed the draconian laws imposed on 13 December 1981. The number of internees fluctuated between the imposition of martial law to the date it was suspended in December 1982, which closed the possibility of interning people. Still, however, strict laws were in force, aimed against civil freedoms, which - after martial law was lifted - were introduced into the Civil Code.

Keywords: martial law, internees, imprisoned, convicted, amnesties, Solidarność, political opposition

Problem internowanych i uwięzionych po 13 grudnia 1981 r. jest poruszany we wszystkich publikacjach dotyczących stanu wojennego, gdyż należał do najbardziej dolegliwych i trwałych jego przejawów. Wśród wielu publikacji należy wyróżnić tom Stan wojenny w Polsce 1981-1983, pod redakcją Antoniego Dudka oraz monografię Andrzeja Paczkowskiego Wojna polsko-jaruzelska. Stan wojenny w Polsce 13 XII 1981 - 22 VII 
$1983^{1}$. Autorzy tych opracowań nie koncentrują się jednak na problemie internowań i aresztowań, a zatem też nie śledzą liczb i dynamiki tego zjawiska. Próbę taką podjął niżej podpisany kilka lat temu (Stan wojenny - statystyka represji, „Wolność i Solidarność” 2011, 2), obecnie ponawiam ją na podstawie kwerend przeprowadzonych w dalszych zespołach archiwalnych. Poniższy artykuł nie jest historią konkretnych ośrodków internowania, problemów więziennictwa w tym okresie, polityki karnej itp., ale wyłącznie sprawozdaniem z badań, w których chodziło o określenie liczby represjonowanych w poszczególnych kategoriach i dynamiki tego zjawiska w ciągu kilku lat. Stan wojenny został zniesiony w lipcu 1983 r., tak więc $\mathrm{w}$ zasadzie należało by przerwać narrację $\mathrm{w}$ tym momencie. $\mathrm{W}$ istocie jednak problem aresztowanych $\mathrm{w}$ stanie wojennym został rozwiązany w lipcu 1984 r. wraz z kolejną amnestią. Tytułem dodatku ułatwiającego podsumowanie problemu dołączyłem także dane dotyczące aresztowań między 1984 a 1986 r., kiedy ostatnia amnestia była równoznaczna z zaniechaniem stosowania sankcji prokuratorskich i w zamyśle procesów do walki z opozycją polityczną. Niniejszy artykuł oparty jest niemal wyłącznie na rozproszonej dokumentacji archiwalnej przechowywanej w Archiwum Akt Nowych (głównie Wydział Administracyjny KC PZPR) oraz Instytucie Pamięci Narodowej.

Pomysł internowania osób aktywnych w Niezależnym Samorządnym Związku Zawodowym „Solidarność” i znanych z przedsierpniowej działalności opozycjonistów pojawił się jesienią 1980 r. w ramach przygotowań władz PRL do ewentualnej „konfrontacji”. Podobnej formuły pozbawienia wolności nie stosowano wcześniej w PRL, a słowo kojarzyło się przede wszystkim z internowaniem polskich władz i żołnierzy w Rumunii i na Węgrzech po kampanii wrześniowej 1939 r. W niektórych dokumentach Ministerstwa Spraw Wewnętrznych z jesieni 1980 r. pisano o zamiarze prewencyjnego aresztowania wybranych osób w wypadku konfrontacji między władzami PRL a Solidarnością. W najstarszym odnalezionym dokumencie dotyczącym tej sprawy, pochodzących z 4 grudnia $1980 \mathrm{r}$. zadaniach Wydziału III-2 Komendy Stołecznej Milicji Obywatelskiej, pisano: „Na wypadek PZ [poważnego zagrożenia] przewiduje się zatrzymanie 133 osób w jednym rzucie (plan w Inspektoracie Komendanta d.s. SB [Służby Bezpieczeństwa]". W tym samym czasie przygotowywano znacznie obszerniejsze listy osób „przewidzianych do izolowania na

1 Stan wojenny w Polsce 1981-1983, red. A. Dudek, Warszawa 2003; A. Paczkowski, Wojna polsko-jaruzelska. Stan wojenny w Polsce 13 XII 1981 - 22 VII 1983, Warszawa 2006; także: M. Marcinkiewicz, Ośrodki odosobnienia 1981-1982. Wierzchowo Pomorskie, Jaworze, Darłówek i Głębokie, Gdańsk-Szczecin 2016. Artykuł powstał w ramach projektu „Solidarność geneza rewolucji, mobilizacja i demobilizacja ruchu" (0214/NPRH2/H11/81/2013). 
wypadek poważnego zagrożenia", obejmujące przeważnie osoby znane z działalności opozycyjnej przed sierpniem $1980 \mathrm{r}$.

W „Notatce w sprawie przygotowania resortu spraw wewnętrznych na wypadek wprowadzenia stanu wojennego ze względu na bezpieczeństwo państwa", podpisanej 14 lutego 1981 r. przez gen. Józefa Beima, przewidywano internowanie 13,5 tys. osób w skali kraju. Decyzje mieli podejmować wojewódzcy komendanci MO. „Akcja internowania nastąpi w ciągu jednej nocy poprzedzającej ogłoszenie stanu wojennego". W innym dokumencie z tego dnia, sygnowanym przez Kierownika Sztabu MSW stwierdzano, że sprawność przeprowadzenia internowania „może mieć decydujący wpływ na rozwój sytuacji w kraju i powodzenie naszych działań”, a zależy też od „pełnego zaskoczenia przeciwnika”2.

W dokumencie „Myśl przewodnia wprowadzenia na terytorium PRL stanu wojennego ze względu na bezpieczeństwo państwa”, podpisanym 27 marca 1981 r. przez I sekretarza KC PZPR Stanisława Kanię i prezesa Rady Ministrów Wojciecha Jaruzelskiego, określano zasady ewentualnego wprowadzenia stanu wojennego na całym terytorium PRL. Wśród zadań dla różnych ogniw władzy, w tym dla MSW, przewidywano sprawne przeprowadzenie akcji internowania, „którą zamierza się rozpocząć w godzinach nocnych po wejściu w życie dekretu [o wprowadzeniu stanu wojennego]"3.

Szerzej problem i zakres internowań omówił minister spraw wewnętrznych gen. Czesław Kiszczak na posiedzeniu Komitetu Obrony Kraju 13 września 1981 r. w referacie o przygotowywanym stanie wojennym. Internowanie miało polegać na pozbawieniu wolności na mocy decyzji komendanta wojewódzkiego MO, a internowani mieli być osadzeni w ośrodkach penitencjarnych podległych ministrowi sprawiedliwości. Zwolnienie z internowania miało następować po uchyleniu stanu wojennego lub na drodze indywidualnej decyzji komendanta wojewódzkiego MO. Minister przewidywał internowanie 4948 osób, które „prowadzą działalność zagrażającą bezpieczeństwu państwa w warunkach stanu wojennego, w szczególności wszystkich 63-ch członków KKP [Krajowej Komisji Porozumiewawczej NSZZ „Solidarność” - A.F.], aktywiści KOR [tj. Komitetu Samoobrony Społecznej „KOR”] (220), KPN [Konfederacji Polski Niepodległej] (107) i innych grup antysocjalistycznych, działacze NZS

2 AIPN, 113/37, „Notatka w sprawie przygotowania resortu spraw wewnętrznych na wypadek wprowadzenia stanu wojennego ze względu na bezpieczeństwo państwa", 14 II 1981, k. 189-192; AIPN, 113/37, „Tezy do podsumowania Kierownika Sztabu MSW gry decyzyjnej 14 lutego 1981", b.d., k. 551-552.

3 AIPN, 1405/92, „Myśl przewodnia wprowadzenia na terytorium PRL stanu wojennego ze względu na bezpieczeństwo państwa”, 27 III 1981, k. 8-17. 
[Niezależnego Zrzeszenia Studentów] prowadzący szkodliwą działalność polityczną, organizatorów strajków itp. Gros zatrzymanych stanowić będą aktywiści kierownictw regionalnych, wiejskich i zakładowych [organizacji] «Solidarności»". Ośrodki odosobnienia, w których zostaną umieszczeni, miała obsługiwać służba więzienna. Akcja internowania powinna się zacząć o północy, „w dniu, w którym wejdzie w życie uchwała Rady Państwa PRL o wprowadzeniu stanu wojennego i dekret o stanie wojennym, które ogłoszone zostaną w godzinach rannych". Generał przewidywał też przeprowadzenie "rozmów polityczno-ostrzegawczych" z około 6 tys. obywateli w celu ich „zneutralizowania”. „Negatywny wynik tych rozmów spowoduje internowanie tych osób". Internowanie miało być stosowane w całym okresie obowiązywania stanu wojennego ${ }^{4}$.

Od września w odpowiednich jednostkach MSW i komend wojewódzkich MO dokonywano przeglądu i weryfikacji list osób przeznaczonych do internowania, typując niektórych na „rozmowy profilaktyczno-ostrzegawcze", ale i dopisując innych. Funkcjonariusze SB dokonywali wizji lokalnych w przypadku każdej osoby, by ustalić sposób wejścia do mieszkania i zredukowania do minimum możliwości ucieczki. Na początku grudnia 1981 r. kryptonim akcji internowań zmieniono z „Wrzos” na "Jodła"5.

Na mocy ogłoszonego 13 grudnia $1981 \mathrm{r}$. dekretu o stanie wojennym ulegały zawieszeniu lub ograniczeniu prawa obywateli, w szczególności nietykalności osobistej, nienaruszalności mieszkań, zrzeszania się, wolności słowa, druku, zgromadzeń, wieców, pochodów i manifestacji. Zawieszono prawo do strajku i akcji protestacyjnych. $\mathrm{W}$ art. 15 pisano: „Jeżeli działalność stowarzyszenia, związku zawodowego, zrzeszenia albo organizacji społecznej lub zawodowej godzi w ustrój polityczny i społeczny lub w porządek prawny Polskiej Rzeczypospolitej Ludowej [--] działalność taka może być zawieszona". Na tej podstawie zawieszona została działalność NSZZ „Solidarność”, podobnie innych związków zawodowych i większości stowarzyszeń. W art. 42 pisano: „Obywatele polscy mający ukończone lat 17, w stosunku do których ze względu na dotychczasowe zachowanie się zachodzi uzasadnione podejrzenie, że pozostając na wolności nie będą przestrzegać porządku prawnego albo prowadzić będą działalność zagrażającą interesom bezpieczeństwa lub obronności państwa, mogą być internowani na czas obowiązywania

${ }^{4}$ Kserokopia dokumentu w zbiorach Instytutu Studiów Politycznych PAN.

5 Por. szerzej A. Paczkowski, Droga do „mniejszego zła”. Strategia i taktyka obozu władzy, lipiec 1980 - styczeń 1982, Kraków 2002; A. Friszke, Rewolucja Solidarności. 1980-1981, Kraków 2014, s. 301, 351-352, 625, 877-879. 
stanu wojennego w ośrodkach odosobnienia”. Decyzję o internowaniu wydawał komendant wojewódzki MO, doręczano ją w momencie zatrzymania i podlegała natychmiastowemu wykonaniu. Przysługiwała na nią skarga do ministra spraw wewnętrznych, nie przewidziano możliwości odwołania się do sądu. Mogła być uchylona przed zniesieniem stanu wojennego, ,jeżeli w tym czasie ustaną przyczyny uzasadniające internowanie". Regulamin pobytu internowanych w ośrodkach odosobnienia miał ogłosić minister sprawiedliwości w porozumieniu z ministrem spraw wewnętrznych.

Integralną częścią dekretu były specjalne przepisy karne. Na podstawie art. 46 kontynuowanie działalności w zawieszonym związku zawodowym lub stowarzyszeniu podlegało karze więzienia do lat 3, organizowanie lub kierowanie strajkiem - do lat 5 . Za rozpowszechnianie wiadomości mogących wywołać niepokój publiczny lub rozruchy przewidziano karę od 6 miesięcy do 5 lat, a jeśli miało to na celu osłabienie obronności - do lat 8. Jeśli czyny te były popełnione przy użyciu „druku lub innego środka masowej komunikacji”, zagrożenie karą zwiększało się do 10 lat więzienia. Rada Państwa uchwaliła również dekret o przekazywaniu do prokuratury i sądów wojskowych spraw o niektóre przestępstwa $z$ dekretu o stanie wojennym. Przewidziano też postępowanie w trybie doraźnym, którym objęto 87 rodzajów przestępstw, m.in. publiczne nawoływanie do nieposłuszeństwa ustawie, napaść na funkcjonariusza publicznego, udział w związku, którego istnienie lub cel mają pozostać tajemnicą przed władzami, naruszanie przepisów dekretu o stanie wojennym, organizację i kierowanie strajkiem. Najniższy wyrok w trybie doraźnym wynosił 3 lata, najwyższy 25 lat więzienia lub kara śmierci ${ }^{6}$.

\section{Internowani i aresztowani}

Według sporządzonego w maju 1982 r. sprawozdania z działalności Sztabu MSW „Lato '80”, który koordynował wprowadzanie stanu wojennego, w nocy z 12/13 grudnia 1981 internowano 3172 osoby, do końca grudnia dalszych 2620, w styczniu 1982 r. kolejnych 588, łącznie zatem 6320 osób, ale internowań dokonywano też w następnych miesiącach w lutym 289 osób, w marcu 295, w kwietniu 233. Od 13 grudnia 1981 r. do 30 kwietnia 1982 internowano łącznie 7198 osób. Wśród nich było 2507 etatowych pracowników Solidarności, jako członków nielegalnych

${ }^{6}$ Dekret z dnia 12 grudnia 1981 r. o stanie wojennym, „Dziennik Ustaw” (dalej: Dz.U.) 1981, nr 29, poz. 154. 
ugrupowań opozycji (KSS „KOR”, KPN, Ruchu Obrony Praw Człowieka i Obywatela - ROPCiO) określano 669 internowanych ${ }^{7}$.

Zestawienie datowane 5 stycznia 1982 r. ukazuje geografię internowań. Zestawieniem objęto internowane 2653 osoby. Najwięcej osób w województwach: gdańskim - 257, wrocławskim - 197, katowickim 191, kieleckim -179 , warszawskim -108 , toruńskim -80 , bielskim 79. Relatywnie mniej internowano w wielkich i aktywnych regionach Solidarności, tj. w województwach: szczecińskim - 63, krakowskim 40, łódzkim -61 , poznańskim -81 , lubelskim -41 , bydgoskim -35 . W świetle tych danych może zaskakiwać liczba internowanych w małych i niezbyt aktywnych ośrodkach: województwach: elbląskim - 76, gorzowskim - 37, krośnieńskim - 41, leszczyńskim - 30, nowosądeckim - 47, opolskim - 42, płockim - 37, radomskim - 46, rzeszowskim - 51, skierniewickim - 36, tarnobrzeskim - 70, wałbrzyskim -77 , zamojskim $-44^{8}$. Proporcje te wskazują, że typowanie do internowania odbywało się na szczeblu wojewódzkim, przy czym w niektórych regionach oszczędniej planowano ten środek pozbawienia wolności, w innych zamierzano nim objąć jak największą liczbę działaczy Solidarności.

Równolegle z kierowaniem do internowania trwał proces zwalniania części internowanych - w grudniu 752 osoby, w styczniu 1230, w lutym 700, w marcu 1090, w kwietniu 1023. Część z tych zwolnień, ale tylko część!, była skutkiem podpisania deklaracji lojalności, względnie współpracy. Od 13 grudnia do 30 kwietnia 1982 r. przeprowadzono z internowanymi 12976 rozmów, oświadczenie o lojalności podpisało 3684, zgodę na współpracę z SB 928.

SB, dysponując narzędziem zastraszania, jakim była groźba internowania, przeprowadziła ponadto 26291 rozmów ostrzegawczych z innymi osobami, pozostającymi na wolności. Połowę takich rozmów przeprowadzono w grudniu $1981 \mathrm{r}$. W ich wyniku pozyskano do współpracy 5719 osób. Klauzula „pozyskany do współpracy” oznaczała, że taka osoba

7 AIPN, 0398/29, t. 1, „Raport z działalności Sztabu w ramach operacji «Lato 80» w okresie od 16 sierpnia 1980 do 30 kwietnia 1982 r.", Warszawa maj 1982, k. 50-51. Opis przebiegu akcji internowania w różnych miastach por. Stan wojenny w Polsce 1981-1983.

8 AIPN, 0236/315, t. 3, „Dane statystyczne akcji «Jodła» i «Klon» za okres 13.12.1981 r. do 5.01.1982 r.", k. 110-113. Por. T. Kozłowski, J. Olaszek, Internowani w stanie wojennym. Dane statystyczne, „Pamięć i Sprawiedliwość” 2010, 2 (16).

9 AIPN, 0398/29, t. 1, „Raport z działalności Sztabu w ramach operacji «Lato 80» w okresie od 16 sierpnia 1980 do 30 kwietnia 1982 r.", Warszawa maj 1982, k. 50-51. Tylko od 13 do 20 grudnia 1981 przeprowadzono rozmowy z 5171 osobami, z których 4749 złożyło deklarację lojalności. „Osoby, które odmawiają złożenia deklaracji lojalności, są z reguły internowane (379 osób)" - mówił Kiszczak 20 grudnia 1981 r. Tego samego dnia mówił o pozyskaniu do współpracy 1597 osób od 13 grudnia. AIPN, 01428/9, 
zgodziła się podpisać zobowiązanie, względnie poprzestano na zgodzie ustnej, po czym danego człowieka zarejestrowano jako osobowe źródło informacji. Nie znaczy to jednak, że współpraca została realnie podjęta i była potem kontynuowana. Część zwerbowanych istotnie ją podjęła, część próbowała się wywikłać, część po zwolnieniu odmówiła współpracy, stawiania się na spotkania itd. Niektórzy z pozyskanych złożyli wnioski o emigrację. Podane liczby nie informują więc, ilu było agentów w środowisku Solidarności, tylko ile osób się załamało w obawie przed długotrwałym pozbawieniem wolności, utratą kontaktu z rodziną itd. Z załamania można jednak było próbować się podnieść.

Wedle zestawienia sporządzonego na dzień 22 marca 1982 r., wśród 3334 wówczas przebywających $\mathrm{w}$ ośrodkach internowania dominowali mężczyźni (3116), robotnicy (1187) i inteligenci (1003); studentów było 186, rolników 85. Około trzech czwartych określano jako członków Solidarności (2317, w tym 446 jej pracowników etatowych). Osobno kwalifikowano członków „nielegalnych organizacji (b. KSS-KOR, KPN, KOWzP [Komitet Obrony Więzionych za Przekonania], ROPCiO, RMP [Ruch Młodej Polski] i in.)" - 299 osób. Członków NZS było 99, członków NSZZ „Solidarnośćc" Rolników Indywidualnych $-85^{10}$.

Według informacji opracowanej w Departamencie V MSW 8 stycznia 1982 r. internowano 74 spośród 107 członków Komisji Krajowej. Spośród internowanych członków KK podjęto rozmowy z 47 osobami, uzyskując wynik pozytywny w 21 przypadkach. „Osoby te krytycznie oceniają polityczną działalność aktywu «Solidarności», odcinają się od elementów ekstremalnych i nielegalnych organizacji antysocjalistycznych, takich jak KSS «KOR», KPN, deklarują się za robotniczym charakterem związku zawodowego «Solidarność»". Ten opis sugeruje, że owych 21 członków KK nie wykluczało możliwości podjęcia się udziału w tworzeniu zamierzonej przez władze „robotniczej” Solidarności ${ }^{11}$. Podobny, pozytywny dla władz wynik, dały rozmowy z 13 nieinternowanymi członkami KK. Spośród 47 członków KK, z którymi SB podjęła rozmowy, 22 dały skutek dla władz negatywny. „Osoby te wybielają własną działalność, jak również całego kierownictwa «Solidarności». Obwiniają władze państwowe

„Informacja dot. działań Ministerstwa Spraw Wewnętrznych i Ministerstwa Obrony Narodowej w okresie trwania stanu wojennego", 20 XII 1981, k. 336, 343.

10 AIPN, 01428/9, „Dane osobowopoznawcze o internowanych”, 22 III 1982, k. 393. Por. T. Kozłowski, J. Olaszek, op. cit., gdzie podane podobne dane syntetyczne z grudnia $1982 \mathrm{r}$.

11 Por. A.Friszke, „Solidarność” zastępcza. Historia z PRL-u, „Ale historia” 14 III 2016, http:// wyborcza.pl/alehistoria/1,121681,19757806,solidarnosc-zastepcza-historia-z-prl-u.html (dostęp: 26 V 2017). 
za spowodowanie i pogłębienie kryzysu gospodarczego. Zamiary przejęcia władzy w Polsce określają «wymysłem propagandy». Wprowadzenie stanu wojennego traktują jako ostateczny argument warstwy rządzącej. Oświadczają, że tylko «demokratycznie» przeprowadzone wybory w Polsce mogą uzdrowić atmosferę w kraju". Do tej grupy należeli spośród znanych działaczy m.in. Andrzej Gwiazda, Seweryn Jaworski, Tadeusz Kensy, Stanisław Kocjan, Antoni Kopaczewski, Grzegorz Palka, Andrzej Rozpłochowski, Jan Rulewski, Andrzej Sobieraj, Antoni Stawikowski, Lech Wałęsa, Henryk Wujec. W Departamencie III planowano podjęcie rozmów z dalszymi 29 członkami KK, w tym 27 internowanymi ${ }^{12}$.

Mimo ogłoszonej z dniem 13 grudnia abolicji ${ }^{13}$, do kwietnia $1982 \mathrm{r}$. SB wszczęła postępowanie przygotowawcze przeciw 121 internowanym, w tym 90 członkom Solidarności, 18 członkom NZS, 18 członkom KPN, 13 członkom i współpracownikom KSS „KOR”14. Już 20 grudnia 1981 r. min. Kiszczak pisał w sprawozdaniu, najpewniej dla faktycznie rządzącego PRL „dyrektoriatu”15, że „przeprowadzona zostanie ocena zabezpieczenia materiałów pod kątem uzyskania dowodów warunkujących wszczęcie postępowania karnego przeciwko aktywistom b. KSS «KOR», NZS, NSZZ «Solidarność» o przygotowywanie spisku antypaństwowego"16. W kwietniu 1982 r. pisano o prowadzonym postępowaniu przygotowawczym i zamiarze postawienia zarzutów 12 „ekstremistycznym działaczom NSZZ «Solidarność»".

Ponadto od 13 grudnia do końca kwietnia 1982 r. wszczęto 5083 postępowania przygotowawcze w trybie doraźnym przeciw 6793 osobom, przy czym przeciw 1569 podejrzanym o przestępstwa określone w dekrecie o stanie wojennym oraz 5080 obwinianym o przestępstwa kryminalne. W ramach tych postępowań aresztowano 6600 osób, do sądów skierowano 4307 aktów oskarżenia przeciw 4569 osobom, w tym 1047 oskarżonym o przestępstwa z dekretu o stanie wojennym. Sądy rozpatrzyły 2195 spraw przeciw 3386 osobom i skazały 764 osoby za przestępstwa $\mathrm{z}$ dekretu o stanie wojennym, 2610 za przestępstwa

12 AIPN, 0649/15, „Informacja dot. członków Komisji Krajowej NSZZ «Solidarność»", 8 I 1982, k. 128-133.

13 Dekret z dnia 12 grudnia 1981 r. o przebaczeniu i puszczeniu w niepamięć niektórych przestępstw i wykroczeń, Dz.U. 1981, nr 29, poz. 158.

14 AIPN, 0398/29, t. 1, „Raport z działalności Sztabu w ramach operacji «Lato 80» w okresie od 16 sierpnia 1980 do 30 kwietnia 1982 r.", Warszawa maj 1982, k. 50-51.

15 Por. A. Paczkowski, Wojna polsko-jaruzelska, s. 66-69.

16 AIPN, 01428/9, „Informacja dot. działań Ministerstwa Spraw Wewnętrznych i Ministerstwa Obrony Narodowej w okresie trwania stanu wojennego", 20 XII 1981, k. 337. 
kryminalne ${ }^{17}$. W opracowaniu nie omawiano kryterium odróżnienia przestępstw określonych w dekrecie z 13 grudnia od przestępstw kryminalnych. Można jednak założyć niemal z pewnością, że rzucanie kamieniami, podejmowanie walki z milicją, czyli typowe zachowania w czasie rozbijanych przez ZOMO demonstracji, traktowano jako przestępstwa kryminalne. Wśród aresztowanych z dekretu o stanie wojennym byli m.in. organizatorzy strajków i podziemnych struktur. W zakończeniu raportu pisano, że „działania operacyjno-polityczne uniemożliwiły powstanie centralnego ośrodka kierowania działalnością nielegalnych grup”. Na przykład w Bydgoszczy zatrzymano 19 podejrzanych o przynależność do Ogólnopolskiego Komitetu Oporu, wobec dziewięciu zastosowano areszt tymczasowy. W Gdańsku w czasie przeszukania pomieszczeń zajmowanych przez Eugeniusza Szumiejkę „ustalono adresy szeregu osób z terenu całego kraju, które prowadzą działalność konspiracyjną" (SB nie udało się aresztować Szumiejki, który zbiegł, ale „wpadły” jego notatki). We Wrocławiu zatrzymano 12 osób, kolportujących pismo „Z Dnia na Dzień”. Jednostki MSW „prowadzą aktywne działania operacyjno-rozpoznawcze w ramach poszukiwania ukrywających się ekstremalnych działaczy Solidarności, m.in. Zbigniewa Bujaka". 23 kwietnia w Warszawie przeprowadzono akcję przeszukań 34 mieszkań osób mogących współpracować z Bujakiem. Aresztowano sześć osób, zakwestionowano wrogie materiały propagandowe, środki poligraficzne, ujawniono punkty przechowywania „bibuły” ${ }^{18}$.

W miarę pacyfikowania masowego oporu celem władz było ograniczenie liczby internowanych, szczególnie zatrzymanych wraz z wprowadzeniem stanu wojennego. Z końcem kwietnia zwolniono 800 internowanych, a dalszych 200 urlopowano ${ }^{19}$. Wówczas w ośrodkach pozostało 2,4 tys. osób. Niemniej po manifestacjach i demonstracjach 1 i 3 maja 1982 r. internowano kolejnych i 1 czerwca w obozach znajdowało się 3,1 tys. osób ${ }^{20}$. Niemniej zwalnianie internowanych odbywało się, przede wszystkim dzięki usilnym staraniom Episkopatu Polski, zwłaszcza abp. Bronisława Dąbrowskiego, który wręcz zasypywał min. Kiszczaka konkretnymi i dobrze umotywowanymi prośbami ${ }^{21}$. Interwencje te mogły

17 AIPN, 0398/29, t. 1, „Raport z działalności Sztabu w ramach operacji «Lato 80» w okresie od 16 sierpnia 1980 do 30 kwietnia 1982 r.", Warszawa maj 1982, k. 52-53.

18 Ibidem, k. 55-56. Por. T. Chinciński, Kto to jest „Mieszko”? Bydgoski Ogólnopolski Komitet Oporu, „Czasy Nowożytne” 21, 2008, s. 129-146.

19 AIPN, 01428/9, Projekt komunikatu z odręcznymi poprawkami, k. 239.

${ }^{20}$ AAN, PZPR, LI/22, „Informacja o stosowaniu prawa okresu stanu wojennego (stan na dzień 6 sierpnia 1982)" (oprac. w Wydziale Administracyjnym KC PZPR, 12 VIII 1982), b.pag.

${ }^{21}$ P. Raina, Troska o internowanych. Interwencje abp. Dabrowskiego u gen. Kiszczaka 1982-1989, Warszawa 1999. 
być tak dobrze udokumentowane dzięki ogromnej pracy, jaką wykonywał Prymasowski Komitet Pomocy Osobom Pozbawionym Wolności i ich Rodzinom, który gromadził informacje o internowanych, docierał do ośrodków z pomocą żywnościową, lekarską, przygotowywał materiały, które mogły służyć staraniom o uwolnienie ${ }^{22}$.

Władze PRL od wiosny 1982 r. czuły się jednak zwycięzcami w walce z Solidarnością i w ramach postępującej normalizacji dążyły do zmniejszenia liczby internowanych. Brak dotychczas opracowania, które w systematyczny sposób analizowałoby politykę władz w tym względzie. Niemniej ograniczanie liczby internowanych postępowało, szczególnie latem 1982 r., kiedy zwolniono ogromną większość robotników oraz wszystkie kobiety. Liczbę ośrodków internowania zmniejszono z 21 do 12 . Tę dynamikę oddaje liczba przetrzymywanych w Białołęce, gdzie 21 czerwca było osadzonych 251 osób, a 23 sierpnia 74 osoby, w tym 11 w szpitalach, a 25 na przepustce ${ }^{23}$. Według notatki Wydziału Administracyjnego KC PZPR od wprowadzenia stanu wojennego do początków sierpnia internowanie zastosowano wobec 8538 osób, a uchylono je wobec $7647^{24}$. W całym kraju 11 sierpnia było 891 internowanych, ale 289 spośród nich przebywało na urlopie, z którego na ogół już za kraty nie wrócilii ${ }^{25}$. Niemniej po manifestacjach 31 sierpnia internowano 189 osób ${ }^{26}$.

Część internowanych zwalniano wskutek wyrażenia przez nich zgody na emigrację z Polski. Zachętę do emigracji sformułował wobec nich sam gen. Jaruzelski w oficjalnym przemówieniu wygłoszonym w Sejmie 25 stycznia 1982 r., a oficerowie SB oddziaływali bezpośrednio. Od 1 marca do 10 czerwca wnioski o paszport złożyło 574 internowanych lub zwolnionych z internowania oraz 827 członków ich rodzin z zamiarem emigracji do krajów zachodnich. Decyzje pozytywne wydano 554 internowanym lub zwolnionym z internowania. Wśród nich było 20 członków Komisji Krajowej, 76 członków zarządów regionów, 245 członków komisji zakładowych Solidarności ${ }^{27}$. Akcja była kontynuowana w następnych

22 Por. W. Rodowicz, Komitet na Piwnej. Fakty, dokumenty, wspomnienia, Warszawa 1994.

${ }^{23}$ My internowani... Białołeka 1981-1982, red. W. Borowik, Warszawa 2011, s. 73, 82.

24 AAN, PZPR, LI/22, „Informacja o stosowaniu prawa okresu stanu wojennego (stan na dzień 6 sierpnia 1982)" (oprac. w Wydziale Administracyjnym KC PZPR, 12 VIII 1982), b.pag.

${ }^{25}$ Ibidem.

${ }^{26}$ AAN, PZPR, LI/22, „Informacja o konsekwencjach prawnych w związku z wydarzeniami w dniu 31.08 br. i dni następnych" (oprac. w Wydziale Administracyjnym KC PZPR, 15 X 1982), b.pag.

27 AIPN, 0236/315, t. 3, „Załącznik do informacji dziennej”, 12 VI 1982 (przekazany W. Jaruzelskiemu, K. Barcikowskiemu, M. Milewskiemu, S. Olszowskiemu, F. Siwickiemu i M. Rakowskiemu), k. 116-118. 
miesiącach i przyczyniła się do znaczącego zdekompletowania wybranej na Krajowym Zjeździe Delegatów Solidarności Komisji Krajowej oraz osłabienia kadr działaczy Związku, zwłaszcza w niektórych regionach.

$\mathrm{Na}$ początku sierpnia Kazimierz Barcikowski mówił przedstawicielom Kościoła, że „władze nie chcą popełnić wobec internowanych tych samych błędów, jakie popełniły po 1945 roku wobec członków AK [Armii Krajowej]"28. Słowa te oddawały intencje bardziej umiarkowanej części aparatu władzy, ale liczba pozbawionych wolności była nadal bardzo wysoka. Według notatki Wydziału Administracyjnego KC PZPR do 6 sierpnia $1982 \mathrm{r}$. w prokuraturach powszechnych wszczęto 5,7 tys. spraw przeciw 6525 osobom, w tym 637 z dekretu o stanie wojennym a 5,9 tys. oskarżono o przestępstwa kryminalne. Aresztowano 6,4 tys. osób, w tym 656 z dekretu o stanie wojennym. Do sądów skierowano akty oskarżenia przeciw 4097 osobom, w tym 467 oskarżonym z artykułów dekretu o stanie wojennym, pozostałych oskarżono o czyny kryminalne. W dokumencie nie określono wyraźnie, o jakie czyny kryminalne chodziło i czy część skazywanych z tych paragrafów nie była sprawcami czynów wynikających z przeciwstawiania się władzy. W prokuraturach wojskowych wytoczono sprawy przeciw 2797 osobom, w tym przeciw 1300 z dekretu o stanie wojennym, a spośród nich aresztowano 1253, z których skazano 1061, w większości za kontynuowanie działalności związkowej lub organizowanie akcji protestacyjnych. Do sądów powszechnych wpłynęły sprawy o przestępstwa polityczne przeciw 556 osobom, z których 408 skazano. Większość - 244 osoby - otrzymała wyroki do 3 lat więzienia. Na 3 lata skazano 89 osób, na karę do 5 lat 9 osób, pozostałym wymierzono kary grzywny lub aresztu. Karę pozbawienia wolności warunkowo zawieszono 101 skazanym. Sądy wojskowe rozpoznały sprawy 1425 osób, skazując 1245. Z dekretu o stanie wojennym sądzono 669 osób, z artykułów kodeksu karnego o czyny kryminalne 756. Wyroki do 3 lat wymierzono 441 osobom, 3 lat -289 , od 3 do $5-241,5$ do $7-29$, a 7 osobom powyżej 7 lat więzienia. Kary nieizolacyjne otrzymało 413 osób ${ }^{29}$. Wśród skazanych przez sądy wojskowe było 39 etatowych działaczy Solidarności i 461 zwykłych członków Związku, przy czym 41 było członkami $\mathrm{PZPR}^{30}$. Analizy dotyczące powodów skazań na Dolnym Śląsku wskazują,

28 P. Raina, Arcybiskup Dąbrowski w stużbie Kościoła i narodu. Rozmowy z władzami PRL, t. 2: 1982-1989, Warszawa 1995, s. 41.

${ }^{29}$ AAN, PZPR, LI/22, „Informacja o stosowaniu prawa okresu stanu wojennego (stan na dzień 6 sierpnia 1982 r.)" (oprac. w Wydziale Administracyjnym KC PZPR, 12 VIII 1982), b.pag.

${ }^{30}$ AAN, PZPR, LI/22, „Dane liczbowe dot. skazanych działaczy i członków NSZZ «Solidarność»" (oprac. w Wydziale Administracyjnym KC PZPR, 12 VIII 1982), b.pag. 
że najczęściej był to kolportaż nielegalnych druków, działalność związkowa, udział w demonstracji i strajku ${ }^{31}$.

Po wielkich akcjach protestacyjnych 31 sierpnia 1982 r., w których zginęły cztery osoby, a rannych było co najmniej 219 osób, zatrzymano w 27 województwach 5514 osób. Kolegia karno-orzekające ukarały grzywną lub aresztem 3023 osoby, do sądów skierowano sprawy przeciw 127, z których skazano 82 . W sprawach uznanych za poważniejsze prokuratury wszczęły śledztwa w trybie doraźnym przeciw 501 tymczasowo aresztowanym. Do połowy października sądy rozpoznały sprawy przeciw 148 osobom, z czego skazały 78, uniewinniły 24, pozostałe przekazały prokuraturze celem uzupełnienia materiału dowodowego. W sprawach rozpoznanych wymierzano kary 3-4 lat pozbawienia wolności w większości za czynną napaść na milicjantów i udział w zbiegowisku publicznym, którego uczestnicy dopuścili się gwałtownych zamachów na osoby lub mienie ${ }^{32}$.

Największą kategorię represjonowanych w stanie wojennym tworzyli skazani przez kolegia do spraw wykroczeń. Od 13 grudnia 1981 do początku sierpnia 1982 r. kolegia ukarały 164 tys. osób, w tym ponad 157 tys. grzywną, a 5633 aresztem. Około 80 proc. skazano za naruszenie przepisów o godzinie milicyjnej, a zatem w pierwszych miesiącach stanu wojennego ${ }^{33}$.

\section{Zawieszenie stanu wojennego - nadzwyczajny tryb ułaskawień}

W grudniu 1982 r. stan wojenny został „zawieszony”. Nie oznaczało to anulowania części represyjnych przepisów, które nadal miały obowiązywać w ramach tego „zawieszenia”. Zlikwidowano jednak ośrodki internowania i status internowanego. Ostatni pozbawieni wolności internowani zostali zwolnieni, choć wobec wybranej grupy przywódców zastosowano aresztowanie i postawiono im zarzuty o podejmowanie przygotowań do obalenia przemocą ustroju PRL (art. 123 kodeksu karnego). Oskarżeniem tym objęto 2 i 3 września 1982 r. sześciu członków KSS „KOR”,

31 Stan wojenny $w$ Polsce 1981-1983, s. 67.

32 AAN, PZPR, LI/22, „Informacja o konsekwencjach prawnych w związku z wydarzeniami w dniu 31.08 br. i dni następnych" (oprac. w Wydziale Administracyjnym KC PZPR, 15 X 1982), b.pag.

${ }^{33}$ AAN, PZPR, LI/22, „Informacja o stosowaniu prawa okresu stanu wojennego (stan na dzień 6 sierpnia 1982 r.)" (oprac. w Wydziale Administracyjnym KC PZPR, 12 VIII 1982), b.pag. 
a 22 grudnia siedmiu członków Komisji Krajowej. Naczelna Prokuratura Wojskowa prowadziła przeciw nim śledztwo realizowane przez Biuro Śledcze MSW, a oskarżeni byli osadzeni w więzieniu mokotowskim.

W okresie „zawieszenia stanu wojennego” represyjność wyraźnie miała się zmniejszyć. Prócz zniesienia statusu internowanego zmierzano także do stopniowego zwalniania osób skazanych w stanie wojennym. Służyła temu uchwała Rady Państwa z 20 grudnia 1982 r. o szczególnych zasadach postępowania ułaskawieniowego. Zapowiadała ona szersze stosowanie indywidualnych aktów łaski wobec osób skazanych za przestępstwa popełnione z motywów politycznych. Jak obliczano w Prokuraturze Generalnej, za kontynuowanie działalności związkowej, organizowanie strajków i protestów, rozpowszechnianie "fałszywych wiadomości” do 31 grudnia 1982 r. skazano 1531 osób, w tym bez warunkowego zawieszenia kary 835. Spośród nich 225 osób skazano na karę do roku więzienia, a zatem w chwili wejścia w życie uchwały Rady Państwa przebywały one już na wolności. O ułaskawienie mogło się ubiegać 610 osób. Inna grupa skazanych - 176 osób - odbywała karę za napaść na funkcjonariuszy podczas demonstracji. Trzecia grupa, to skazani za lżenie narodu, PRL i jej ustroju - 108 osób. Łącznie więc skazanych mogących ubiegać się o ułaskawienie było $894^{34}$.

Podane tu liczby mogą budzić wątpliwości w porównaniu z notatką Wydziału Administracyjnego KC PZPR z sierpnia 1982 r., gdzie pisano o skazaniu 1245 osób przez sądy wojskowe (w tym co najmniej 669 za przestępstwa z dekretu o stanie wojennym) oraz 408 przez sądy powszechne za kontynuowanie działalności związkowej lub organizowanie strajków. A przecież od sierpnia do grudnia 1982 r. skazywano następnych. Być może różnica wynika z obejmowania statystyką także kar z zawieszeniem oraz faktu, że część została skazana na kary do roku więzienia. W innym dokumencie z połowy 1983 r. pisano, że od 13 grudnia 1981 do maja 1983 r. za przestępstwa polityczne sądy powszechne i wojskowe skazały 2788 osób, ale w większości orzekały kary nieizolacyjne ${ }^{35}$.

Do 10 czerwca 1983 r. wpłynęły wnioski ułaskawieniowe 796 osób, z czego 428 złożyli sami skazani, 154 ich rodziny, 135 obrońcy, 119 kolektywy pracownicze, 55 organizacje społeczne, w tym nowe związki zawodowe. (Ten tryb, dopuszczający wnioski nie tylko skazanego, ale też jego rodziny, obrońcy, a nawet środowiska pracy pokazuje, że rezygnowano

34 AAN, PZPR, LI/124, „Informacja o realizacji uchwały Rady Państwa z dnia 20 grudnia 1982 r. w sprawie szczególnych zasad postępowania ułaskawieniowego" (13 VI 1983 r., oprac. wiceprokurator D. Cytowska), b.pag.

35 AAN, PZPR, LI/125, „Informacja o stosowaniu prawa w okresie zawieszenia stanu wojennego..." (oprac. w MSW w maju 1983), b.pag. 
z obowiązku upokorzenia się skazanego, by osiągnąć szerszy efekt zwalniania). Rada Państwa skorzystała z prawa łaski wobec 679 skazanych, odmawiając łaski 116 osobom. Wśród tych, którym odmówiono nadzwyczajnego złagodzenia kary, było

50 sprawców przestępstw powodujących ciężkie skutki materialne, moralne i polityczne - przywódców działalności antysocjalistycznej, organizatorów strajków stosujących metody terroru i zastraszania załóg robotniczych oraz powodujących znaczne straty z powodu przerwania produkcji (Wrocławski Mostostal - 3000000 szkody, kopalnia „Andaluzja” w Piekarach śl., kopalnia Węgla Kamiennego "Jankowiec” w Rybniku - organizator strajku przygotowywał wysadzenie kopalni).

Dalszych 48, którym odmówiono złagodzenia kar, to recydywiści, 9 osób zachowujących się niepoprawnie w więzieniach, m.in. organizatorów protestów oraz 9 członków nielegalnych organizacji „mających na celu prowadzenie akcji terrorystycznych" ${ }^{36}$. Jak pisano w analizie przeprowadzonej przez Ministerstwo Sprawiedliwości, do 30 kwietnia 1983 r. zakłady karne opuściły 344 osoby, w tym 221 skazanych za czyny wymienione $\mathrm{w}$ dekrecie o stanie wojennym ${ }^{37}$.

Miejsca zwalniane w aresztach i więzieniach zapełniali następni. od początku roku do 15 maja 1983 r. wszczęto 478 postępowań o charakterze politycznym wobec 795 osób, z których 488 aresztowano. Najwięcej spraw dotyczyło „rozpowszechniania antypaństwowej propagandy”, czyli udziału w tworzeniu i kolportowaniu wydawnictw podziemnych. Takimi oskarżeniami objęto 321 osób, z których 220 aresztowano. Druga grupa pod względem wielkości to oskarżeni o kontynuowanie działalności w Solidarności - 227 podejrzanych, w tym 150 aresztowanych ${ }^{38}$. Między początkiem stycznia a początkiem czerwca 1983 r. prawomocne wyroki zapadły wobec 51 osób oskarżonych o czyny z dekretu o stanie wojennym popełnione przed 20 grudnia $1982 \mathrm{r}^{39}$ Liczby te wskazywały

36 AAN, PZPR, LI/124, „Informacja o realizacji uchwały Rady Państwa z dnia 20 grudnia 1982 r. w sprawie szczególnych zasad postępowania ułaskawieniowego" (13 VI 1983 r., oprac. wiceprokurator D. Cytowska), b.pag.

37 AAN, PZPR, LI/124, „Informacja dotycząca stosowania prawa karnego w okresie zawieszenia stanu wojennego" (oprac. w Ministerstwie Sprawiedliwości datowana 25 maja 1983), b.pag.

38 AAN, PZPR, LI/125, „Informacja o stosowaniu prawa w okresie zawieszenia stanu wojennego..." (oprac. w MSW w maju 1983), b.pag.

39 AAN, PZPR, LI/124, „Informacja o realizacji uchwały Rady Państwa z dnia 20 grudnia 1982 r. w sprawie szczególnych zasad postępowania ułaskawieniowego" (13 VI 1983 r., oprac. wiceprokurator D. Cytowska), b.pag. 
na trwanie oporu i zorganizowanej działalności, co zresztą było widoczne w postaci licznych tytułów prasy podziemnej, wydawnictw książkowych oraz trwałej aktywności struktur podziemnych szczebla centralnego i regionalnego. MSW oceniało, że następuje „postęp stabilizacji życia w kraju”, ale „poczynania politycznego przeciwnika ciągle jeszcze zawierają groźbę poważnego naruszenia bezpieczeństwa ładu i porządku w kraju. Poczynaniom przeciwnika sprzyja nie zakończony jeszcze proces odwracania skutków rozchwiania i deprecjacji podstawowych wartości moralnych [sic!] oraz braku poszanowania prawa, które charakteryzowały lata 1980-81". Resort oceniał w tym kontekście negatywnie stosowanie kar nieizolacyjnych, warunkowego zawieszenia kar lub orzekania kar grzywny. „Ta praktyka orzecznictwa budzi zastrzeżenia, zwłaszcza ze względu na ograniczenie prewencyjnego oddziaływania kary, stwarzania skazanym możliwości uchodzenia za pokrzywdzonych oraz [ma] demobilizujący wpływ na pracowników organów ścigania"40.

Istotnie, sądy orzekały w tych sprawach najczęściej możliwie niskie kary. W okresie od 1 stycznia do 25 maja 1983 r. z art. 46. dekretu o stanie wojennym (kontynuowanie działalności związkowej lub organizowanie strajku bądź manifestacji) sądy wojewódzkie osądziły 25 osób, skazując 21 (84 proc.), wobec pozostałych umorzono postępowanie. Na kary do 3 lat więzienia skazano 20 osób, wobec wszystkich zastosowując warunkowe zawieszenie kary. Jedna osoba otrzymała karę grzywny. W 10 wypadkach wyroki zostały zaskarżone przez prokuratora, przy czym w okresie sprawozdawczym Sąd Najwyższy rozpoznał rewizje wobec trzech osób, podtrzymując wyroki. W tym samym czasie sądy rejonowe osądzily 54 osoby, skazując 50 i uniewinniając 4. Kary do 3 lat więzienia wymierzono 49, grzywny jednej osobie. Zarazem 39 osobom skazanym zawieszono kare pozbawienia wolności ${ }^{41}$.

\section{Amnestia 1983 roku}

Postępowanie władz PRL zmierzających do ograniczenia liczby więźniów skazanych z przyczyn politycznych (w PRL nie było statusu więźnia politycznego) wynikało m.in. z ich pewnej wrażliwości na postulaty wysuwane przez Episkopat Polski i Jana Pawła II. Kościół konsekwentnie

40 AAN, PZPR, LI/125, „Informacja o stosowaniu prawa w okresie zawieszenia stanu wojennego..." (oprac. w MSW w maju 1983), b.pag.

${ }^{41}$ AAN, PZPR, LI/124, „Informacja dotycząca stosowania prawa karnego w okresie zawieszenia stanu wojennego" (oprac. w Ministerstwie Sprawiedliwości, 25 V 1983, aprobował pierwszy zastępca ministra T. Skóra), b.pag. 
domagał się w 1982 r. zwolnienia internowanych, a także postulował amnestię $^{42}$. W wariancie „normalizacji”, realizowanym przez ekipę Jaruzelskiego, istotne było nieantagonizowanie Kościoła, który był uważany za ważny czynnik stabilizujący sytuację w kraju. Władzom zależało na tym, by biskupi i duszpasterze nie wspierali ani idei powrotu Solidarności do legalnego istnienia, ani tym bardziej solidarnościowego podziemia. Zarazem władze były skłonne tolerować oddziaływanie na członków zdelegalizowanego Związku w duchu umiarkowania, stopniowego akceptowania sytuacji. Władze PRL nie mogły sobie pozwolić na antagonizowanie papieża Jana Pawła II, gdyż jego autorytet w wielkim stopniu określał sytuację w Polsce, był także bardzo istotnym czynnikiem wpływającym na sytuację kraju na arenie międzynarodowej. To wszystko powodowało podatność na argumenty strony kościelnej o konieczności łagodzenia reżimu, a zwłaszcza uwolnienia najpierw internowanych, następnie więźniów sumienia.

Mimo opublikowania wielu materiałów dotyczących stosunków Kościół - państwo, bardzo szczupła jest dokumentacja dotycząca tych stosunków w pierwszej połowie 1983 r., kiedy przygotowywano wizytę w Polsce Jana Pawła II. Można jednak założyć, że problem więźniów był jedną z ważnych dyskutowanych kwestii. Temat więzionych podniósł Jan Paweł II w liście do przewodniczącego Rady Państwa Henryka Jabłońskiego z 21 kwietnia 1983 r., zwracając się z gorącą prośbą „o uwolnienie wszystkich skazanych i sądzonych z dekretu stanu wojennego

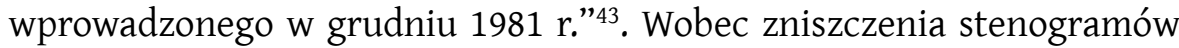
posiedzeń Biura Politycznego KC PZPR nie ma możliwości zrekonstruowania dyskusji, która z pewnością toczyła się na tym forum w sprawie stosunków z Kościołem, wizyty w Polsce papieża w czerwcu tego roku oraz sprawy więźniów politycznych i ewentualnej amnestii, a przede wszystkim problemów związanych ze zniesieniem stanu wojennego, co nastąpiło w lipcu 1983.

Projekt dokumentu pt. „Założenia aktu amnestyjnego” trafił na posiedzenie Sekretariatu KC PZPR 2 lipca 1983 r. W artykule 1 pisano, że ustawa amnestyjna dotyczy przestępstw popełnionych z powodów politycznych lub w związku ze strajkiem lub akcją protestacyjną, a objętych dekretem z 12 grudnia 1981 r. o abolicji. Dotyczy także uszkodzeń ciała dokonanych $\mathrm{w}$ związku ze strajkiem lub innym naruszeniem $\mathrm{z}$ powodów politycznych bezpieczeństwa i porządku publicznego, działań

${ }^{42}$ Por. A. Micewski, Kościół wobec „Solidarności” i stanu wojennego, Paryż 1987.

43 List opublikował P. Raina, Wizyty Apostolskie Jana Pawła II w Polsce. Rozmowy przygotowawcze Watykan - PRL - Episkopat, Warszawa 1997, s. 189-190. 
w celu wywołania niepokoju publicznego lub rozruchów, nielegalnego posiadania i wyrabiania radiowego aparatu nadawczego, nieodstąpienia od działalności w zawieszonym Związku, organizowania lub kierowania strajkiem względnie akcją protestacyjną, rozpowszechniania fałszywych wiadomości, sporządzania i gromadzenia nielegalnych pism, druków, nagrań. Amnestia miała objąć także ucieczki z ośrodków dla internowanych. Sprawcom tych „przestępstw” zamierzano darować kary, jeśli czyny, których się dopuścili, są zagrożone karą do lat 3, względnie wyższą, ale na takie kary zostali skazani. Wyroki powyżej 3 lat łagodzi się o połowę, a do kar złagodzonych sąd penitencjarny może zastosować warunkowe przedterminowe zwolnienie po odbyciu połowy wyroku. Amnestia była warunkowa $\mathrm{w}$ tym sensie, że $\mathrm{w}$ wypadku popełnienia do 31 grudnia 1985 r. przez sprawcę przestępstwa, do którego zastosowano amnestię, „amnestia podlega cofnięciu; umorzone postępowanie podejmuje się a darowane kary wykonuje się - odpowiednio w całości lub części".

Istotne znaczenie miał artykuł 2 projektu ustawy, który stanowił, że przebacza się i puszcza w niepamięć przestępstwa wyżej wymienione, których sprawcy pozostają na wolności i nie przedstawiono im zarzutu, o ile zgłoszą się oni do 31 grudnia 1983 r. do organów wymiaru sprawiedliwości, ścigania przestępstw, względnie placówki dyplomatycznej lub konsularnej „oraz ujawnią rodzaj popełnionego przestępstwa, czas i miejsce jego popełnienia" 44 .

Ustawa amnestyjna została zredagowana tak, aby objęła możliwie wszystkie rodzaje czynów związanych z protestami przeciw wprowadzeniu stanu wojennego czy organizowania różnych form aktywności podziemnej, w tym wydawania i kolportażu prasy podziemnej, z wyjątkiem jednak liderów Solidarności, którym postawiono zarzuty względnie skazano ich na kary wyższe niż 3 lata więzienia. Zastrzeżenie to nie dotyczyło przywódców nadal się ukrywających - w tym wypadku chodziło o spowodowanie ich ujawnienia się. Zarazem zastrzeżenie dotyczące anulowania amnestii w wypadku podjęcia ponownej aktywności miało sprawić, by możliwie duża część zwalnianych odsunęła się od dalszej aktywności. Amnestia była więc po części aktem humanitarnym, ale po części narzędziem zmierzającym do osłabienia rozmiarów solidarnościowego podziemia.

Ustawa o amnestii została wydana przez Sejm z okazji święta 22 Lipca i była związana ze zniesieniem stanu wojennego ${ }^{45}$. W jej wykonaniu

${ }^{44}$ AAN, PZPR, V/201, „Załącznik na posiedzenie Sekretariatu KC PZPR 2 lipca 1983", k. 7-12.

${ }^{45}$ Ustawa z dnia 21 lipca 1983 r. o amnestii, Dz.U. 1983, nr 39, poz. 177. 
darowano 365 osobom karę bezwzględnego pozbawienia wolności, a kolejnym 385 inne kary zasadnicze. O połowę złagodzono kary powyżej 3 lat 116 osobom. Umorzono postępowanie karne prowadzone przez sądy i prokuraturę wobec 1116 osób. Amnestię zastosowano także wobec 1108 osób ukaranych przez kolegia do spraw wykroczeń. Z zakładów karnych zwolniono warunkowo po odbyciu połowy kary 113 osób. Swoją działalność ujawniły do 31 grudnia 1983 r. 1132 osoby $^{46}$. Liczby te nie odnoszą się wyłącznie do uczestników protestów lub podziemnej Solidarności, gdyż amnestią objęto również czyny nieumyślne i np. wykroczenia drogowe. Bardziej szczegółowe dane pozwalające wyodrębnić grupę „politycznych” zawierała informacja przekazana do KC PZPR przez prokuraturę. W prokuraturach powszechnych uchylono tymczasowe aresztowanie wobec 251 osób oraz umorzono postępowanie przygotowawcze wobec 381 podejrzanych o przestępstwa polityczne i na tle konfliktów społecznych. Prokuratorzy wojskowi uchylili tymczasowe aresztowanie wobec 24 osób oraz umorzyli postępowanie wobec 20 podejrzewanych o czyny popełnione z powodów politycznych. Podane tu kategorie nie dotyczą osób już skazanych przez sądy.

W trybie artykułu 2 ustawy zgłosiły się do władz śledczych lub prokuratur, względnie przedstawicielstw dyplomatycznych PRL, 1132 osoby. Wśród nich było 671 członków Solidarności, w tym czterech działaczy szczebla krajowego, 37 regionalnego i 137 zakładowego, 11 członków KPN i 10 członków rozwiązanego NZS. „Najczęściej popełniane przestępstwa to: kolportaż nielegalnych wydawnictw i organizowanie oraz zbieranie pieniędzy i innych datków dla osób pozostających w «podziemiu»". Do 31 grudnia 1983 r. prokuratorzy wydali postanowienia o odmowie wszczęcia postępowania przygotowawczego wobec 516 osób, które zgłosiły „popełnienie przestępstw o charakterze politycznym” oraz umorzono postępowanie przygotowawcze wobec 36 osób, które zgłosiły popełnienie takich „przestępstw”"

Z amnestii 1983 r. nie skorzystali skazani członkowie KPN (4 osoby), członkowie KSS „KOR” i Solidarności (11 osób), w stosunku do których trwały nadal przygotowania do procesu. Nie uwolniono również skazanych po 13 grudnia przywódców Solidarności, organizujących akcje protestacyjne, np. Andrzeja Słowika i Władysława Frasyniuka lub nadal przebywającego w areszcie Józefa Piniora.

${ }^{46}$ AAN, PZPR, V/234, „Informacja o realizacji ustawy o amnestii z 1983 r. (na podstawie danych Ministerstwa Sprawiedliwości, Prokuratury Generalnej i Ministerstwa Spraw Wewnętrznych)", k. 18-19.

${ }^{47}$ AAN, PZPR, XIA/1453, „Informacja o realizacji ustawy z dnia 21 lipca 1983 r. o amnestii", k. 192-193. 


\section{Amnestia 1984 roku}

Zniesienie w lipcu 1983 r. stanu wojennego zamykało formalnie i prawnie okres obowiązywania ustawodawstwa wprowadzonego 13 grudnia 1981 r. Rzecz jest jednak bardziej skomplikowana, gdyż do ustaw wprowadzono niektóre przepisy „sprawdzone” w okresie stanu wojennego, m.in. pozwalające na zaostrzone ściganie czynów związanych z oporem wobec władzy, działalnością podziemną i wydawaniem nielegalnych druków. Już sam akt amnestii z lipca 1983 r. stanowił o anulowaniu jej dobrodziejstw w razie ponownego podjęcia działalności.

W drugiej połowie $1983 \mathrm{r}$. wszczęto 324 postępowania karne o przestępstwa polityczne, które objęły 553 osoby, spośród których aresztowano 334. Dalsze aresztowania następowały w 1984 r. W pierwszym półroczu jednostki śledcze SB wszczęły 550 spraw o przestępstwa polityczne przeciw 1190 osobom, z których 760 aresztowano. Przeważnie chodziło o „rozpowszechnianie ulotek i nielegalnych wydawnictw”. W tej sprawie prowadzono 174 postępowania obejmujące 392 podejrzanych, w tym 293 aresztowanych. Ponadto w sprawach o udział „w związkach przestępczych, których uczestnicy sporządzali i kolportowali takie ulotki i wydawnictwa" prowadzono 124 postępowania obejmujące 404 podejrzanych, spośród których aresztowano 243. Tylko w maju 1984 r. skonfiskowano 84 tys. ulotek oraz 31 tys. broszur i wydawnictw ${ }^{48}$.

Genezę kolejnej amnestii należy wiązać z nierozwiązaną przez amnestię lipcową 1983 r. sprawą jedenastu przywódców KSS „KOR” i Solidarności. Inicjatywa należała do kierownictwa Episkopatu, które 26 września 1983 r. skierowało Pro memoria do Komisji Wspólnej rządu PRL i Episkopatu. W dokumencie podnoszono, że przygotowywany wobec KSS „KOR” będzie „proces o słowa, w którym brak jakichkolwiek materialnych elementów przygotowań do zamachu stanu". Podobnie proces przywódców Solidarności wywoła oburzenie na całym świecie, a w odczuciu milionów członków Związku będzie sądem nad ich organizacją. „Skutki psychologiczne tej sprawy mogą nasuwać analogie z problemem AK, który zaciążył nad całą epoką powojennych dziejów Polski”. Biskupi sugerowali, że najstosowniejszym rozwiązaniem obu spraw byłoby wykorzystanie artykułu 5 ustawy z 21 lipca 1983 r., który pozwala Sądowi Najwyższemu umorzyć na wniosek prokuratora generalnego każde postępowanie śledcze „W szczególnie uzasadnionych wypadkach” ${ }^{49}$. To Pro memoria

48 AIPN, 1585/206, Sprawozdanie z działalności Biura Śledczego MSW za 1984 r., k. 86-89.

${ }^{49}$ AIPN, 514/4, t. 51, „Pro memoria na Komisję Wspólną”, 26 IX 1983, k. 218-220. 
zapoczątkowało proces negocjowania sprawy zasad uwolnienia ,jedenastki" między przedstawicielami Kościoła a gen. Kiszczakiem ${ }^{50}$.

Przebieg tych negocjacji jest odrębnym tematem ${ }^{51}$. Jako karty przetargowej, mającej skłonić ,jedenastu” do kapitulacji, władze stawiały los pozostałych więźniów. Ich uwolnienie wiązano z zadeklarowaniem przez „,jedenastu” wycofania się po uwolnieniu z działalności opozycyjnej. Ostatecznie w połowie kwietnia 1984 r. gotowy był zestaw dokumentów, które określały tryb zwalniania ,jedenastki”: list prymasa Józefa Glempa do przewodniczącego Rady Państwa Henryka Jabłońskiego z prośbą o objęcie amnestią uwięzionych przywódców; odpowiedź przewodniczącego Rady Państwa z zapowiedzią zwrócenia się do prokuratora generalnego i Sądu Najwyższego o zastosowanie wobec uwięzionych amnestii, jeśli wstrzymają się oni od działalności politycznej; wzór listu prymasa do poszczególnych aresztowanych i wzór ich odpowiedzi: „Po zapoznaniu się z listem Księdza Prymasa z dnia... 1984 r. oraz załączonymi do niego dokumentami wyrażam gotowość zaniechania publicznej działalności politycznej w rozumieniu określonym w załączniku nr $2 \mathrm{w}$ okresie do 31 grudnia 1986 r." ${ }^{52}$. Tak wypracowana kapitulacja z niezłomności nie została zrealizowana wobec stanowczego sprzeciwu Adama Michnika, który odmówił podjęcia negocjacji, oraz ostatecznego odrzucenia oferty przez pozostałych dziesięciu oskarżonych.

Niepowodzenie próby doprowadzenia przywódców KSS „KOR” i Solidarności do wycofania się z życia publicznego, co musiałoby złamać ich autorytet, było porażką władz, ale paradoksalnie były one przygotowane na taką ewentualność i co najmniej od stycznia zamierzały kolejną amnestię $^{53}$. W maju 1984 r. w więzieniach PRL przebywało 95800 osób, w tym 725 uwięzionych z przyczyn politycznych ( 58 skazanych, 514 tymczasowo aresztowanych w postępowaniu przygotowawczym i 153 tymczasowo aresztowanych pozostających w dyspozycji sądów) ${ }^{54}$. W czerwcu 1984 r.

50 Por. P. Raina, Troska o internowanych; A. Orszulik, Czas przełomu. Notatki ks. Alojzego Orszulika z rozmów z władzami PRL w latach 1981-1989, Warszawa-Ząbki 2006; B. Geremek, Doradcy i więźniowie, „Wolność i Solidarność” 2012, 4, s. 113-130; J. Skórzyński, Odrzucona propozycja. Rozmowy o uwolnienie przywódców „Solidarności” 1983-1984, „Wolność i Solidarność" 2012, 4, s. 104-112.

${ }^{51}$ Por. J. Skórzyński, op. cit., s. 104-112.

52 P. Raina, Troska o internowanych, s. 221-224; J. Skórzyński, op. cit., s. 107.

53 AIPN, 0204/1417, t. 56, „Koncepcje polityczno-prawne zakończenia postępowań karnych przeciwko członkom kierownictwa antypaństwowego związku pn. «KSS-KOR» i ekstremistycznym działaczom b. «Solidarności»", 13 II 1984, k. 26-36. Autorem dokumentu był Kiszczak.

54 AAN, PZPR, V/234, „Informacja o skazanych, ukaranych i tymczasowo aresztowanych", 31 V 1984 r., k. 20. 
jednostki śledcze SB wszczęły 144 sprawy o przestępstwa polityczne przeciw 249 osobom, z których 181 aresztowano ${ }^{55}$.

Na posiedzenie Biura Politycznego KC PZPR wpłynęła notatka w sprawie amnestii na czterdziestolecie PRL. Amnestia miała objąć także te przestępstwa popełnione z powodów politycznych, które nie były objęte amnestią z 1983 r. Należałoby więc w stosunku do przestępstw popełnionych z powodów politycznych: „darować wszystkie orzeczone kary zasadnicze bez względu na wymiar; umorzyć toczące się postępowania przygotowawcze lub sądowe wobec sprawców przestępstw popełnionych z powodów politycznych; przebaczyć i puścić w niepamięć wykroczenia popełnione z powodów politycznych przed terminem wskazanym w ustawie, a niewykonane kary - darować". Amnestia powinna objąć osoby skazane, podejrzane lub oskarżone o przestępstwa z art. 123, 128, 132, 133 kodeksu karnego, a więc członków KPN, KOR i „ekstremę Solidarności". Spod dobrodziejstwa ustawy byliby wyłączeni oskarżeni o zdradę ojczyzny, szpiegostwo, sabotaż, dywersję, zdradę dyplomatyczną, wielkie afery gospodarcze. Zamierzano powtórzyć możliwość zgłaszania się do organów ścigania lub przedstawicielstw dyplomatycznych PRL i zawiadamiania o popełnionych czynach karalnych „z określeniem jego rodzaju, czasu i miejsca" oraz zobowiązania się do zaniechania przestępczej działalności. „Doniosłość rocznicy oraz szeroki akt łaski wobec sprawców przestępstw popełnionych z powodów politycznych, w tym zbrodni z art. 123 kk przemawia za szerszym aniżeli w 1983 r. dobrodziejstwem amnestii dla sprawców przestępstw pospolitych". W dokumencie omawiano zasady łagodzenia lub umarzania kar sprawców takich czynów. $\mathrm{W}$ osobnym punkcie przewidziano umorzenie postępowania przed niedawno powołanym Trybunałem Stanu, co dotyczyło m.in. byłego I sekretarza KC PZPR Edwarda Gierka. Wzorem ustawy z 1983 r. przewidziano okres próby do 1986 r. "Jeżeli w tym okresie sprawca, do którego zastosowano amnestię popełni nowe umyślne przestępstwo podobne, za które orzeczono karę pozbawienia wolności, orzeczenie o amnestii ulega uchyleniu" 56 . Amnestia wypracowana w celu rozwiązania problemu „jedenastki” objęła więc zarazem trzy kategorie więźniów: 1) skazanych z powodów politycznych, a nieuwolnionych w 1983 r. (m.in. przywódców KPN i skazanych na wysokie kary przywódców Solidarności); 2) wszystkich aresztowanych od czasu poprzedniej amnestii uczestników działań

55 AIPN, 1585/4831, Załącznik do informacji z 6 lipca 1984 r., k. 29.

56 AAN, PZPR, V/234, „Notatka w sprawie zasad amnestii w związku z 40-leciem PRL", 1984, k. 13-17; zob. także pełny tekst ustawy z 21 lipca: Dz.U. 1984, nr 36, poz. 192. 
podziemnej Solidarności; 3) licznych skazanych za czyny kryminalne. W liczbach bezwzględnych ta trzecia grupa była największa.

Do 15 września 1984 r. amnestię zastosowano wobec 321820 osób, w tym 203093 sprawców przestępstw pospolitych, ponad 117 tys. sprawców wykroczeń oraz 1569 „sprawców przestępstw p-ko państwu i porządkowi publicznemu". Wśród tych ostatnich było 106 osób, którym darowano karę pozbawienia wolności oraz 19 osób, które wykonywały karę ograniczenia wolności oraz 1444 osoby, którym umorzono postępowanie karne. Zakłady karne opuściło 34,5 tys. osób, w tym 630 osób aresztowanych lub więzionych z powodów politycznych. W więzieniach i aresztach pozostały 22 osoby z tej grupy, w tym 20 odbywających karę lub tymczasowo aresztowanych w związku z przestępstwami pospolitymi nieobjętymi amnestią. Dwie pozostałe osoby to aresztowani w czerwcu 1984 r. Bogdan Lis, członek Tymczasowej Komisji Koordynacyjnej „Solidarności", i jego współpracownik Piotr Mierzewski, obaj oskarżeni o „szpiegostwo" ${ }^{2}$. (Obaj zostali ostatecznie zwolnieni po dyskusji na posiedzeniu Biura Politycznego KC PZPR 6 grudnia 1984 ${ }^{58}$ ). W analizie dokonanej przez Tadeusza Skórę z Ministerstwa Sprawiedliwości oceniano, że amnestia roku 1984 r. jest największa od lat, zakresem zbliżona do tej z roku $1974^{59}$.

Uchwalona w 1984 r. amnestia nie była związana z łagodzeniem polityki karnej w PRL, a nawet dokonano jej wbrew istniejącym tendencjom. Jak bowiem zauważano w Ministerstwie Sprawiedliwości, rok 1984, mimo amnestii, „zaznaczył się znacznym zaostrzeniem polityki aresztowej”. Przez zakłady karne przeszło ponad 70 tys. osób (w 1983 r. 57 tys.), liczba tymczasowo aresztowanych wzrosła z 22,7 tys. w 1983 do 25,9 tys. w 1984 r. Liczba pozbawionych wolności stale wzrastała i wynosiła w końcu sierpnia 68,3 tys. ${ }^{60}$ Dane te potwierdzają tezę, że amnestia 1984 r. nie była wynikiem „odwilży” w polityce karnej, ale działaniem wynikającym z przyczyn politycznych, mającym na celu zamknięcie problemu zapowiedzianych procesów karnych przywódców KSS „KOR” i Solidarności. Na tej zamykającej problem operacji skorzystali inni

57 AAN, PZPR, LI/117, „Informacja o realizacji amnestii z 1984 r. wg stanu na 20 sierpnia 1984 r." (oprac. w Ministerstwie Sprawiedliwości), b.pag.; AAN, PZPR, LI/128, „Informacja o realizacji ustawy z dnia 21 lipca 1984 r. o amnestii”, 24 IX 1984, b.pag.

58 Por. A. Friszke, Tymczasowa Komisja Koordynacyjna NSZZ „Solidarność” (1982-1987), w: Solidarność podziemna 1981-1989, red. idem, Warszawa 2006, s. 101.

59 AAN, PZPR, LI/117, „Informacja o realizacji amnestii z 1984 r. wg stanu na 20 sierpnia 1984 r." (oprac. w Ministerstwie Sprawiedliwości), b.pag.

60 AAN, PZPR, LI/132, „Notatka uzupełniająca” (oprac. w Ministerstwie Sprawiedliwości b.d. [jesień 1984]). 
więźniowie polityczni i tymczasowo aresztowani oraz cała rzesza osób aresztowanych lub skazanych za czyny kryminalne.

Amnestia 1984 r. nie kończyła represjonowania karnego uczestników działań opozycyjnych. W lutym 1985 r. aresztowani zostali Władysław Frasyniuk, Bogdan Lis i Adam Michnik, których następnie w czerwcu skazano na kary od 2 do 3,5 lat więzienia. W styczniu 1986 r. aresztowano ukrywającego się od 13 grudnia 1981 r. Bogdana Borusewicza, organizatora struktur podziemnych w Gdańsku. 31 maja zatrzymany został Zbigniew Bujak, przewodniczący podziemnego regionu „Mazowsze" oraz jego współpracownicy Konrad Bieliński i Ewa Kulik. Były to wielkie ciosy dla podziemnej Solidarności, ale aresztowania w większości dotyczyły osób mniej znanych. Według danych Komitetu Helsińskiego od amnestii 1984 do lipca 1986 r. postępowaniem karnym z przyczyn politycznych objęto co najmniej 898 osób, w tym 829 aresztowano, a 296 skazano ${ }^{61}$. Według danych, którymi posługiwały się najwyższe władze PRL, w lipcu 1986 r. były 283 osoby pozbawione wolności z przyczyn politycznych. Kolejna amnestia uchwalona przez Sejm 17 lipca 1986 r. $^{62}$, a zwłaszcza jej rozszerzenie we wrześniu tego roku, praktycznie kończyła problem więźniów politycznych w Polsce lat osiemdziesiątych ${ }^{63}$. W więzieniach pozostało jednak kilka osób aresztowanych i oskarżonych o nietypowe czyny polityczne, m.in. kpt. Adam Hodysz, oficer SB, który współpracował z podziemną Solidarnością. Ich uwolnienie nastąpiło w 1988 lub 1989 r.

$*$

Przedstawiony materiał budzi pewne refleksje ogólniejszej natury. Postępowanie władz stanu wojennego w pierwszych miesiącach jego realizacji zmierzało do pozbawienia wolności i izolowania jak największej liczby potencjalnych organizatorów oporu, a listy ułożono wedle obserwowanych przez SB zachowań i aktywności ludzi w różnych środowiskach. Temu samemu celowi były podporządkowane przewidziane w dekrecie o stanie wojennym drakońskie zagrożenia karami za podejmowanie aktów oporu. Chodziło o zastraszenie społeczeństwa i ograniczenie do minimum zarówno sprzeciwów masowych (strajki, demonstracje), jak i rozmiarów działalności podziemnej. Internowanie było też sposobem

61 J. Holzer, K. Leski, Solidarność w podziemiu, Łódź 1990, s. 117.

${ }^{62}$ Ustawa z dnia 17 lipca 1986 r. o szczególnym postępowaniu wobec sprawców niektórych przestępstw, Dz. U. 1986, nr 26, poz. 126.

63 Polska 1986-1989. Koniec systemu. Materiały międzynarodowej konferencji, Miedzeszyn, 21-23 października 1999, t. 3: Dokumenty, red. A. Dudek, A. Friszke, Warszawa 2002, s. 13-19. 
na łamanie charakterów - groźba pozbawienia wolności lub obietnica jej odzyskania miały skłaniać do podpisywania deklaracji lojalności lub współpracy z SB. W miarę słabnięcia masowego oporu zwalniano większość internowanych, co następowało wiosną i latem 1982 r. Niemniej władze były gotowe sięgać po ten środek represji, by zastraszać uczestników masowych wystąpień, zwłaszcza 31 sierpnia 1982 r. Decyzje o internowaniu i zwalnianiu z internowania były w wyłącznej dyspozycji aparatu MSW. On też realizował czynności śledcze w wypadku osób aresztowanych, ale wyroki wydawały sądy wojskowe względnie powszechne. Należy zauważyć tendencję do orzekania kar zarówno przez sądy powszechne, jak i wojskowe, w dolnych granicach możliwości określonych przez dekret o stanie wojennym. Ta tendencja sądów spotykała się z krytyką ze strony MSW.

W okresie zawieszenia stanu wojennego (koniec grudnia $1982-$ 22 VII 1983) naczelne władze PRL przyjęły politykę nadzwyczajnego łagodzenia kar i zwalniania osób skazanych w roku 1982. Wydaje się, że chodziło władzom nie tyle o bezwzględne egzekwowanie wyroków, co zniechęcenie tych, co przeszli przez więzienie, do dalszej aktywności opozycyjnej. Taki też charakter miała ustawa o amnestii uchwalona w lipcu 1983 r. Objęła ona w większości osoby osadzone w aresztach w minionych miesiącach, już po decyzji o zawieszeniu stanu wojennego. Liczba aresztowanych w tych miesiącach wskazywała na nadal znaczną liczbę osób podejmujących działalność na rzecz przywrócenia wolności. To samo powiedzieć należy o liczbie osób aresztowanych między lipcem 1983 a lipcem 1984. Dążenia władz do wymuszenia bierności pod groźbą kary więzienia okazywały się tylko częściowo skuteczne. Nie osiągnęła tego celu również amnestia z lipca 1984 r., o czym świadczy liczba więźniów i aresztowanych z powodów politycznych dwa lata później. Ostatecznie we wrześniu 1986 r. odstąpiono od karania więzieniem za czyny o charakterze opozycyjnym.

W omawianym materiale nie ma zestawień dotyczących powodów skazań w poszczególnych okresach. Wydaje się jednak uzasadniona hipoteza, że do połowy 1982 r. większość skazywano za udział w strajkach, demonstracjach, w następnych miesiącach i latach większość skazanych to działacze podziemnych struktur Solidarności, względnie KPN oraz organizatorzy podziemnego ruchu wydawniczego, w tym drukarze i kolporterzy. Ta kategoria wśród aresztowanych z przyczyn politycznych dominowała do roku 1986. 


\section{Streszczenie}

Do najbardziej charakterystycznych cech stanu wojennego należało internowanie obywateli na zasadzie swobodnej decyzji władz, a także aresztowanie i skazywanie osób, które naruszyły wprowadzone 13 grudnia 1981 r. drakońskie prawa. Liczba internowanych ulegała zmianie od chwili wprowadzenia stanu wojennego do jego zawieszenia, które nastąpiło w grudniu 1982 r., kiedy możliwość internowania przestała istnieć. Nadal jednak obowiązywały drakońskie paragrafy wymierzone przeciw wolnościom obywatelskim, które - po zniesieniu stanu wojennego przeniesiono do kodeksu karnego.

W artykule skupiono się na określeniu skali zjawiska internowania i liczby osób internowanych oraz jej zmienności w okresie 1981-1982. W oparciu o materiał archiwalny autor zestawia liczbę internowanych oraz próbuje zestawić podstawowe dane dotyczące internowanych. Równolegle pokazuje statystykę skazań przez sądy w roku 1982, a także w latach następnych.

W artykule wskazano na cele władz PRL dotyczące represji. Wysoką represyjność zastąpiono od początku 1983 r. dążeniem do zmniejszania liczby więźniów. Finałem tego etapu była amnestia w lipcu 1983 r., która objęła ogromną większość uwiezionych. Niemniej nadal wysoka skala oporu społecznego powodowała ponowne zapełnienie cel więźniami aresztowanymi z powodów politycznych. W lipcu 1984 r. ogłoszono kolejną amnestię, która objęła wszystkich więźniów, w tym nieobjętych amnestią 1983 r. czołowych internowanych działaczy Solidarności, przywódców związkowych skazanych za organizowanie protestów po 13 grudnia 1981 r. i organizowanie działalności podziemnej. Amnestia nie oznaczała jednak zmiany prawodawstwa wymierzonego w tego rodzaju działalność, więzienia zatem znów zapełniały się aresztowanymi w powodów politycznych. Latem $1986 \mathrm{r}$. uchwalono kolejną amnestię, którą objęto wszystkich aresztowanych z powodów politycznych od $1984 \mathrm{r}$. Zarazem postanowiono zaniechać stosowania aresztowania w wypadkach naruszenia zakazu prowadzenia nielegalnej działalności politycznej i związkowej czy rozpowszechniania niecenzurowanych publikacji. Za takie naruszenia obowiązującego prawa wymierzano od tej pory jedynie kary finansowe.

\section{The internees, imprisoned, convicted. People deprived of freedom in the period of martial law 1981-1983/1984}

One of the most characteristic features of martial law in Poland was the internment of citizens based on the arbitrary decision of the authorities, and also the detention and conviction of people who infringed the draconian laws imposed on 13 December 1981. The number of internees fluctuated between the imposition of martial law to the date it was suspended in December 1982, which closed the possibility of interning people. Still, however, strict laws were in force, aimed against civil freedoms, which - after martial law was lifted - were introduced into the Civil Code. 
The article seeks to determine the scale of internment of people and the number of detained together with its changes in 1981-1982. Using archival materials, the author presents the number of internees together with some basic information about them preserved in archival documents. This is juxtaposed with statistics of people convicted by courts in 1982 and in the following years.

The article indicates purposes of the Polish communist government as regards reprisals. In early 1983 extreme victimization was replaced by the tendency to a gradual reduction of the number of prisoners. This stage ended with an amnesty in July 1983. Yet, the large scale of social resistance again made jails full of political prisoners. In July 1984 another amnesty was declared, which included all prisoners, together with the leading Solidarność activists interned on 13 December 1981 who did not fall under the amnesty of 1983, and the trade union leaders convicted for organising protests and developing the underground opposition after 13 December. The amnesty, however, did not bring any changes in the laws against this type of activity, so with the lapse of time the number of political prisoners increased. In the summer of 1986 another amnesty was declared, which included all people arrested for political reasons from 1984. At that time a decision was made to stop arresting people for illegal political and trade-union activities or for distribution of uncensored publications. From that time on, only fines were imposed for such an infringement of the law.

Translated by Grażyna Waluga

\section{Bibliografia}

Chinciński Tomasz, Kto to jest „Mieszko”? Bydgoski Ogólnopolski Komitet Oporu, „Czasy Nowożytne" 21, 2008, s. 129-146.

Friszke Andrzej, Rewolucja Solidarności. 1980-1981, Znak Horyzont, Kraków 2014.

Friszke Andrzej, „Solidarność” zastępcza. Historia z PRL-u, „Ale historia” 14 III 2016, http://wyborcza.pl/alehistoria/1,121681,19757806,solidarnosc-zastepczahistoria-z-prl-u.html (dostęp: 26 V 2017).

Friszke Andrzej, Stan wojenny - statystyka represji, „Wolność i Solidarność” 2011, 2, s. 44-52.

Friszke Andrzej, Tymczasowa Komisja Koordynacyjna NSZZ „Solidarność” (1982-1987), w: Solidarność podziemna 1981-1989, red. Andrzej Friszke, ISP PAN, Warszawa 2006

Geremek Bronisław, Doradcy i więźniowie, „Wolność i Solidarność” 2012, 4, s. 113-130. Holzer Jerzy, Leski Krzysztof, Solidarność w podziemiu, Wydawnictwo Łódzkie, Łódź 1990.

Kozłowski Tomasz, Olaszek Jan, Internowani w stanie wojennym. Dane statystyczne, „Pamięć i Sprawiedliwość” 2010, 2 (16), s. 507-510.

Marcinkiewicz Marta, Ośrodki odosobnienia 1981-1982. Wierzchowo Pomorskie, Jaworze, Darłówek i Głębokie, ECS, IPN, Gdańsk-Szczecin 2016.

Micewski Andrzej, Kościół wobec „Solidarności” i stanu wojennego, Editions du Dialogue, Paryż 1987. 
My internowani... Białołęka 1981-1982, red. Wojciech Borowik, Stowarzyszenie Wolnego Słowa, Warszawa 2011.

Paczkowski Andrzej, Droga do „mniejszego zła”. Strategia i taktyka obozu władzy, lipiec 1980 - styczeń 1982, Wydawnictwo Literackie, Kraków 2002.

Paczkowski Andrzej, Wojna polsko-jaruzelska. Stan wojenny w Polsce 13 XII 1981 - 22 VII 1983, Prószyński i S-ka, Warszawa 2006.

Raina Peter, Arcybiskup Dąbrowski w służbie Kościoła i narodu. Rozmowy z władzami PRL, t. 2: 1982-1989, Książka Polska, Warszawa 1995.

Raina Peter, Troska o internowanych. Interwencje abp. Dabrowskiego u gen. Kiszczaka 1982-1989, Wydaw. von Borowiecky, Warszawa 1999.

Raina Peter, Wizyty Apostolskie Jana Pawła II w Polsce. Rozmowy przygotowawcze Watykan - PRL - Episkopat, Książka Polska, Warszawa 1997.

Rodowicz Władysław, Komitet na Piwnej. Fakty, dokumenty, wspomnienia, Biblioteka „Więzi”, Warszawa 1994.

Orszulik Alojzy, Czas przełomu. Notatki ks. Alojzego Orszulika z rozmów z władzami PRL w latach 1981-1989, Apostolicum, Warszawa-Ząbki 2006.

Polska 1986-1989. Koniec systemu. Materiały międzynarodowej konferencji, Miedzeszyn, 21-23 października 1999, t. 3: Dokumenty, red. A. Dudek, A. Friszke, Trio, Warszawa 2002.

Skórzyński Jan, Odrzucona propozycja. Rozmowy o uwolnienie przywódców „Solidarności” 1983-1984, „Wolność i Solidarność” 2012, 4, s. 104-112.

Stan wojenny w Polsce 1981-1983, red. Antoni Dudek, IPN, Warszawa 2003.

Biogram: Andrzej Friszke, profesor w Instytucie Studiów Politycznych Polskiej Akademii Nauk, członek-korespondent Polskiej Akademii Nauk. Zajmuje się historią PRL, szczególnie różnymi przejawami opozycji wobec systemu; kontakt: afriszke@gmail.com. 